\title{
Efek Variasi Konsentrasi NaOH pada Pembentukan Struktur Selulosa Cladophora sp.
}

\author{
Sri Wahyu Suciyati ${ }^{\left(1, a^{*}\right)}$, Posman Manurung ${ }^{(2)}$, Junaidi ${ }^{(2)}$, dan Rudy \\ Situmeang ${ }^{(3)}$ \\ ${ }^{(1)}$ Program Studi Doktor MIPA, FMIPA Universitas Lampung, Bandar Lampung, Indonesia, 35141 \\ (2) Jurusan Fisika, Universitas Lampung, Bandar Lampung, Indonesia, 35141 \\ ${ }^{(3)}$ Jurusan Kimia, Universitas Lampung, Bandar Lampung, Indonesia, 35141 \\ Email : ${ }^{\left(a^{*}\right)}$ sri.wahyu@fmipa.unila.ac.id
}

Diterima (11 November 2021), Direvisi (03 Desember 2021)

\begin{abstract}
The effect of $\mathrm{NaOH}$ concentration values was observed on the cellulose structure of Cladophora. Cladophora cellulose is synthesized from Cladophora sp., a green alga that lives in aquatic environments (seawater and freshwater) and soil surfaces (rocks and wetlands). Cellulose synthesis is carried out through the processes of bleaching, alkali hydrolysis, and acid hydrolysis. Bleaching uses $\mathrm{NaClO}_{2}$, alkaline hydrolysis uses $\mathrm{NaOH}$ with varying concentrations $(0.4 ; 0.5 ; 0.6 ; 0.7 ; 0.8 \mathrm{M})$, while acid hydrolysis uses $5 \%$ $\mathrm{HCl}$. The physical properties of cellulose were analyzed using Fourier Transformation Infra-Red (FTIR) to determine functional groups, X-Ray Diffraction (XRD) to determine crystal structure, and scanning electron microscopy (SEM) to determine the morphology of cellulose structure. FTIR pattern analysis showed peaks with OH group stretching at 3331, 3347, $3360 \mathrm{~cm}^{-1}, \mathrm{CH}$ group stretching at around $2929 \mathrm{~cm}^{-1}, C=O$ stretching at 1640-1650 $\mathrm{cm}^{-1}$, and $\mathrm{CH}_{2}$ flexural stretching at 1420-1430 $\mathrm{cm}^{-1}$ in all samples. XRD pattern analysis confirmed the recovery of Cladophora cellulose from a highly crystalline of sample c ( $\mathrm{NaOH} 0.5 \mathrm{M}$ ) with a crystallinity index of $94.0 \%$ and a particle size of $31.54 \mathrm{~nm}$. SEM image analysis showed the surface morphology of Cladophora rod-shaped raw material with an average diameter of $21.30 \mu \mathrm{m}$. At the same time, Cladophora cellulose refers to the formation of a web-like nanofibril network with an average diameter of $30.63 \mathrm{~nm}$. These results indicate that the synthesis has successfully removed lignin, hemicellulose, and amorphous group in Cladophora and formed crystalline cellulose confirmed by nano-sized cellulose.
\end{abstract}

Keywords: concentration variation, structure of cellulose, Cladophora sp.

Abstrak. Pengaruh nilai konsentrasi $\mathrm{NaOH}$ telah diamati pada struktur selulosa Cladophora. Selulosa Cladophora disintesis dari Cladophora sp., yaitu jenis alga hijau yang hidup pada lingkungan perairan (air laut dan air tawar) dan permukaan tanah (bebatuan dan tanah lembab). Sintesis selulosa dilakukan melalui proses bleaching, hidrolisis alkali, dan hidrolisis asam. Bleaching menggunakan $\mathrm{NaClO}_{2}$, hidrolisis alkali menggunakan $\mathrm{NaOH}$ yang divariasi konsentrasinya $(0,4 ; 0,5 ; 0,6 ; 0,7 ; 0,8 \mathrm{M})$, sedangkan hidrolisis asam menggunakan $\mathrm{HCl} 5 \%$. Karakteristik fisik selulosa dianalisis menggunakan Fourier Transformation Infra Red (FTIR) untuk menentukan gugus fungsi, X-Ray Diffraction (XRD) untuk menentukan struktur kristal, dan scanning electron microscopy (SEM) untuk mengetahui morfologi struktur selulosa. Hasil analisa pola FTIR menunjukkan adanya puncak-puncak dengan peregangan gugus O-H pada puncak 3331, 3347, 3360 $\mathrm{cm}^{-1}$, peregangan gugus $\mathrm{C}-\mathrm{H}$ di sekitar $2929 \mathrm{~cm}^{-1}$, peregangan $\mathrm{C}=\mathrm{O}$ pada $1640-1650 \mathrm{~cm}^{-1}$, dan peregangan lentur $\mathrm{CH}_{2}$ pada $1420-1430 \mathrm{~cm}^{-1}$ di semua sampel. Analisa pola XRD memperkuat perolehan selulosa Cladophora dari sampel c (NaOH 0,5 M) yang sangat kristalin dengan indeks kristalinitas 94,0\%, dan ukuran partikel 31,54 nm. Analisa citra SEM menunjukkan morfologi permukaan bahan baku Cladophora berbentuk batang dengan diameter rata-rata $21,30 \mu \mathrm{m}$, sedangkan selulosa Cladophora mengacu pada pembentukan jaringan nanofibril seperti sarang (web) dengan diameter rata-rata 30,63 nm. Hasil ini menunjukkan sintesis telah berhasil menghilangkan lignin, hemiselulosa, dan bagian amorf pada Cladophora dan membentuk selulosa kristal yang dikonfirmasi oleh selulosa ukuran nano.

Kata kunci: variasi kosentrasi, struktur selulosa, Cladophora sp. 


\section{PENDAHULUAN}

Perkembangan nanosains dan nanoteknologi menjadikan sintesis dan modifikasi nanomaterial dengan struktur dan fungsi yang lebih baik mengalami peningkatan pada hasil dan pengaplikasian yang potensial di bidang nanomaterial [1]. Kemajuan ini sangat menjanjikan di berbagai sektor industri, seperti obatobatan, elektronik, biomaterial dan produksi energi [2][3]. Bidang biomaterial seperti sintesis selulosa juga mengalami perkembangan. Sifatnya yang mudah terurai secara biologis, berkelanjutan, biokompatibel, dan ketersediaanya melimpah, menjadikan selulosa sebagai bahan yang sangat istimewa di kalangan ilmuwan untuk dikembangkan sebagai material maju. Sintesis biasanya dilakukan dengan teknik top-down yang memanfaatkan bahan baku mulai dari tumbuhan tingkat tinggi [4][5], alga [6][7][8], bakteri [9][10][11], hewan laut dan limbah pertanian [12][13][14][15]. Bahan baku dipreparasi membentuk pulp, diisolasi dan diekstraksi menjadi material selulosa berskala nano. Hasil ekstraksi secara umum dikategorikan sebagai Cellulose Nanocrystals (CNC) atau Cellulose Nanofibrils (CNF) tergantung dari metode ekstraksi yang digunakan [16]. CNC adalah partikel-partikel selulosa menyerupai batang (rod-like) dengan ukuran salah satu dimensinya kurang dari $100 \mathrm{~nm}$ dan sifat kristal alamnya tinggi [17][18][19][20]. CNF berbentuk seratserat dengan diameter 20-60 $\mathrm{nm}$ dan panjang beberapa micron [21] mengandung bagian kristal dan amorph.

Selulosa merupakan biopolimer alam terbarukan yang jumlahnya melimpah di alam. Produksi selulosa makin meningkat per tahunnya karena material berbasis selulosa sangat ramah lingkungan, biodegradable dan mampu menggantikan penggunaan bahan baku minyak bumi yang semakin menipis dan tidak ramah lingkungan [22]. Cladophora sp. adalah bahan baku selulosa dari jenis alga yang konsen diteliti karena sifat kristalinitasnya mencapai $95 \%$ [23][24][25][26], luas permukaannya $94,7 \mathrm{~m}^{2} / \mathrm{g}$, dan volume porinya $0,5540 \mathrm{~cm}^{3} / \mathrm{g} \quad[24]$, diameter lebarnya $(10-30 \mathrm{~nm})$ lebih besar dari kayu (5 nm) [27]. Meskipun dari spesies yang sama, tingkat kristalinitas selulosa yang dihasilkan dapat berbeda [26]. Karakteristik unik ini menjadikan selulosa Cladophora sp. sebagai absorber dan filter yang sangat baik untuk pemurnian air [27]dan udara [28], sebagai bahan paper komposit untuk polimer konduktif [29] dan perangkat penyimpan energy [30]. Sintesis selulosa baik CNC maupun CNF dapat dilakukan dengan salah satu metode top-down berikut, hidrolisis (kimia), mekanik dan hidrolisis enzimatik (biologi) [31].

Skema hidrolisis mampu menghilangkan lignin, hemiselulosa, lilin dan minyak yang menutupi permukaan luar dinding sel serat alam [32][33]. Hidrolisis (kimiawi) dengan kombinasi perlakuan mikrofluidisasi atau ultrasound adalah metode kimia yang umum dipakai untuk mengisolasi fase kristalin [8][34] dalam selulosa karena sederhana dan konsumsi energinya rendah. Proses hidrolisis kimia bekerja dengan menghancurkan dan menghilangkan komponen amorf dan menyisakan segmen kristalin [35]. Hal ini terjadi karena kontak serat dengan larutan penghidrolisis (alkalin-asam) memungkinkan daerah amorf mudah diuraikan, dan karena kinetika hidrolisis di daerah ini lebih cepat daripada di kristal, sehingga bahan yang terhidrolisis menjadi lebih permeabel [36].

Berdasarkan hal diatas, proses sintesis selulosa Cladophora sp. di penelitian ini, dilakukan dengan metode hidrolisis kimia, dengan perlakuan awal hidrolisis buffer asetat (bleaching) dan alkalin (lignifikasi) menggunakan sodium hidroksida $(\mathrm{NaOH})$. 
Sodium hidroksida mampu meningkatkan kemurnian $\alpha$-selulosa dan menghilangkan sebagian lignin dan hemiselulosa [37]. Pengendalian konsentrasi $\mathrm{NaOH}$, suhu dan waktu hidrolisis [38] sangat penting untuk menghindari degradasi selulosa yang tidak diinginkan sehingga isolasi selulosa mikrokristal berlangsung sempurna. Hidrolisis asam menggunakan hidroklorida ( $\mathrm{HCl})$ pada Cladophora sp. mempengaruhi sifat permukaan selulosa nanokristal [8][33]. Selain bahan baku selulosa, variabel seperti konsentrasi asam, waktu dan suhu hidrolisis sangat berpengaruh pada ukuran dan morfologi selulosa nanokristal yang dihasilkan [34]. Dari keseluruhan variabel, pengaruh variasi sodium hidroksida dikaji dalam artikel ini melalui gugus fungsi, struktur, dan morfologi selulosa Cladophora sp. yang dihasilkan. Pengujian karakteristik selulosa dilakukan dengan FTIR, XRD dan SEM.

\section{METODE PENELITIAN}

Cladophora sp. yang berasal dari rawa adalah jenis terbaik sebagai bahan baku selulosa [26]. Sampel dibersihkan dari kotoran dan hewan-hewan kecil yang menempel dengan mencucinya pada air yang mengalir, selanjutnya sampel dikeringkan. Bahan-bahan kimia yang digunakan untuk sintesis selulosa adalah $\mathrm{NaClO}_{2}, \mathrm{NaOH}, \mathrm{HCl}$, asam asetat glasial yang semuanya dibeli dari Sigma Aldrich (Merck). Sebelum digunakan, Cladophora sp. dicuci, dikeringkan, dan diblender. Proses isolasi dan ekstraksi secara umum menggunakan prosedur Suciyati, et al. [26]. Cladophora sp. (3 g) di bleaching dengan larutan campuran buffer sodium acetat (30 $\mathrm{mL}, \mathrm{pH}$ 4-5) dengan $\mathrm{NaClO}_{2}$ (1.2 g) selama 3 jam dalam water bath $\left(60{ }^{0} \mathrm{C}\right)$. Bagian padat dipisahkan dan dicuci dengan deionized water (DI water) hingga netral ( $\mathrm{pH} ~ 7)$ menggunakan sentrifuge dengan kecepatan $4000 \mathrm{rpm}$ selama 20 menit. Setelah itu padatan dicampur dengan $\mathrm{NaOH}$
(36 mL; 0,4;0,5;0,6;0,7;0,8M) dan dipanaskan dalam water bath $\left(60{ }^{0} \mathrm{C}\right)$ semalaman. Padatan kemudian dicuci dengan DI water untuk menghilangkan sisa alkalin menggunakan sentrifuge, selanjutnya dikeringkan. Setelah pengeringan, sampel dicampur dengan $\mathrm{HCl}$ $5 \%(18 \mathrm{~mL})$ kemudian dipanaskan $\left(\sim 90{ }^{\circ} \mathrm{C}\right)$ hingga mendidih lalu didinginkan semalaman pada suhu ruang. Sampel ditambahkan aquabides untuk dinetralisasi ( $\mathrm{pH} ~ 7)$ dari pengaruh $\mathrm{HCl}$ dibantu alat sentrifuge untuk mendapatkan selulosa terlarut. Bagian padatan dipisahkan (selulosa), dikeringkan (freeze drying) dan dilakukan pengayakan dengan ayakan 200 mesh untuk memperoleh serbuk selulosa, sehingga penelitian tersebut dapat dilakukan ulang kembali dengan hasil yang sama.

Karakteristik kimia dan fisika selulosa Cladophora sp. diuji melalui serapan spektrum infra merah pada Fourrier Transform InfraRed (FTIR) dan intensitas puncak difraksi X-ray. Komponen biomassa atau gugus fungsi dapat ditentukan secara non-destruktif melalui penyerapan spektrum mid-IR, pada saat bahan diuji menggunakan FTIR (penelitian ini menggunakan mesin Cary 630 merk Agilent). Data direkam dalam range 650$4000 \mathrm{~cm}^{-1}$ untuk 32 kali scan. Karakterisasi struktur kimia dengan FTIR mengidentifikasi gugus fungsional dan intensitas pita serapan inframerah dalam sampel. Pengukuran difraksi sinar X (XRD) pada sampel dilakukan untuk mengetahui phasa krsitalin, dimana pengukuran dilaksanakan oleh tool XRD type PANanalytical: X'Pert Pro diffraction analyzer. Intensitas radiasi yang ditembakkan adalah $\mathrm{Cu}$ K-alpha $(\mathrm{k}=$ $1.540598 \mathrm{~A}^{\circ}$ ) pada $40 \mathrm{kV}$ dan $30 \mathrm{~mA}$ dengan jangkauan sudut $2 \theta$ dari $5^{\circ}$ sampai $90^{\circ}$. Dari data difraktogram XRD dapat diketahui indeks kristalinitas selulosa Cladophora sp. melalui metode empirik 
berbantuan persamaan Segal crystallinity index (CI) seperti Persamaan (1) berikut,

$C I=\frac{I_{\max }-I_{\min }}{I_{\min }} \times 100 \%$

dengan $I_{\max }$ merupakan puncak intensitas tertinggi pada sudut $2 \theta$ disekitar $22,8^{\circ}$, dan $I_{\min }$ adalah intensitas minimum pada sudut $2 \theta$ disekitar $18^{\circ}$ yang berlaku untuk selulosa. Puncak intensitas maksimum berhubungan dengan puncak kristalin, sedangkan puncak intensitas minimum merupakan intensitas hamburan yang dianggap puncak amorph. Dari data difraktogram XRD dapat dihitung ukuran kristal menggunakan persamaan Scherrer,

$\tau=\frac{K \lambda}{B \cos \theta}$

dengan $\tau$ adalah lebar/panjang dalam $\AA, K$ adalah factor koreksi bentuk $(0,9), \lambda$ adalah panjang gelombang radiasi (1,540598 $⿱$ A), $B$ adalah FWHM dari puncak difraksi tertinggi (rad), dan $\theta$ adalah setengah dari sudut puncak tertinggi dalam jangkauan $2 \theta$.

Morfologi permukaan sampel Cladophora sp. dianalisis menggunakan Scanning Electron Microscopy, SEM-EDX ZEISS EVO MA 10, Germany.

\section{HASIL DAN PEMBAHASAN}

\section{Karakterisasi FTIR}

Pengukuran serapan infra merah bahan dilakukan dalam jangkauan panjang gelombang 4000-650 $\mathrm{cm}^{-1}$ dimana dalam spektrum ini terjadi transisi antara keadaan energi vibrasi dan rotasi substrat molekul [41][42]. Karakteristik struktur kimia dan gugus fungsional selulosa dapat diidentifikasi dalam range tersebut berdasarkan puncak-puncak pita penyerapan gelombang infra merah. Keberadaan polimer selulosa, lignin, dan hemiselulosa terdeteksi melalui pola FTIR yang khas. Indikasi daerah kristal dan daerah amorp diketahui pada spektrum
4000-2995 cm $\mathrm{cm}^{-1}, 2900 \mathrm{~cm}^{-1}, 1432 \mathrm{~cm}^{-1}$, $1364 \mathrm{~cm}^{-1}$ dan $900 \mathrm{~cm}^{-1}$ [43]. Gambar 1 menunjukkan karakteristik gugus fungsional selulosa Cladophora sp. dari beberapa variasi konsentrasi sodium hidroksida saat proses delignifikasi dengan konsentrasi $\mathrm{HCl}$ tetap.

Pola FTIR (Gambar 1) menunjukkan perubahan kimia akibat proses ekstraksi material alami Cladophora sp. menjadi selulosa Cladophora. Pada selulosa, serapan spektrum infra merah terdapat pada daerah 3330-3500 $\mathrm{cm}^{-1}$ dengan gugus fungsi utama $\mathrm{O}-\mathrm{H}$, daerah $2800-2900 \mathrm{~cm}^{-1}$ dengan gugus fungsi $\mathrm{C}-\mathrm{H}$, daerah 1035$1060 \mathrm{~cm}^{-1}$ dengan gugus peregangan $\mathrm{C}-\mathrm{O}$ dan puncak $1111 \mathrm{~cm}^{-1}$ merupakan gugus $\mathrm{C}$ O glikosida [44]. Selulosa juga terdeteksi di daerah fingerprint sekitar puncak 1364 $\mathrm{cm}^{-1}$ dan puncak $1400 \mathrm{~cm}^{-1}$ yang menunjukkan gugus lenturan $\mathrm{C}-\mathrm{H}$ dan lenturan $\mathrm{CH}_{2}$ [45]. Perubahan struktur selulosa akibat variasi $\mathrm{NaOH}$ ditunjukkan oleh peregangan $\mathrm{O}-\mathrm{H}$ pada spektrum 3331 , $3347,3360 \mathrm{~cm}^{-1}$ dan peregangan $\mathrm{C}=\mathrm{O}$ pada $1640-1650 \mathrm{~cm}^{-1}$ [43]. Puncak $3331 \mathrm{~cm}^{-1}$ merupakan karakteristik peregangan getaran gugus hidroksil dalam polisakarida yang juga mencakup getaran ikatan

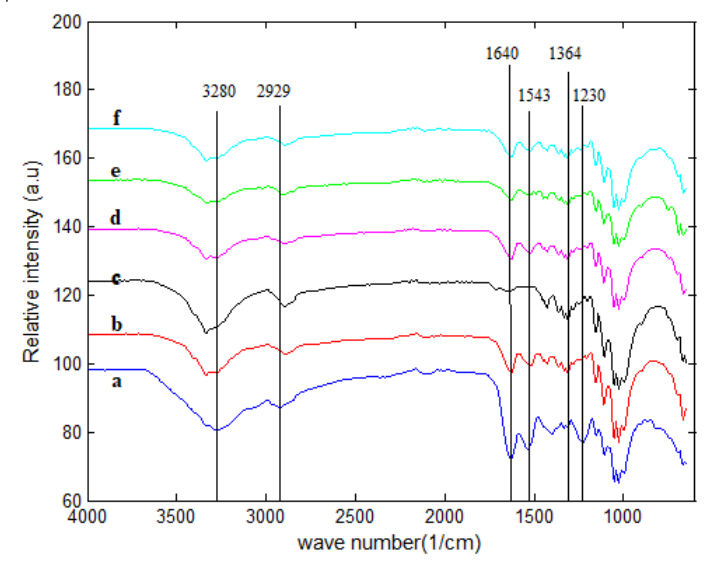

Gambar 1. Spektrum FTIR selulosa Cladophora dengan konsentrasi $\mathrm{HCl} 5 \%$ dan $\mathrm{NaOH}$, (a) raw material; (b) 0,4 M; (c) 0,5 M; (d) 0,6 M; (e) 0,7 M; (f) 0,8 M

hidrogen inter- dan intra-molekular dalam selulosa [46]. Sangat sulit untuk menghilangkan air dari selulosa karena 
adanya interaksi selulosa dengan air akibat ikatan inter- dan intra-molekular dalam selulosa, sehingga pita-pita ini tetap ada setelah treatmen hidrolisis alkali dan asam pada setiap nilai konsentrasi $\mathrm{NaOH}$ yang diberikan [47]. Puncak serapan pada pita 2929 dan $1640 \mathrm{~cm}^{-1}$ merupakan akibat dari peregangan gugus $\mathrm{O}-\mathrm{H}$ dan gugus $\mathrm{C}-\mathrm{H}$ dalam molekul air. Terlihat pada Gambar 1.c, interaksi (vibrasi) molekul air dalam selulosa Cladophora menyebabkan peningkatan intensitas puncak $\left(2929 \mathrm{~cm}^{-1}\right)$, sementara pada puncak $1640 \mathrm{~cm}^{-1}$ terjadi destruksi intensitas puncak yang menandai adanya proses degradasi struktur polimer lignin [48]. Pengaruh hidrolisis alkali pada daerah pita ini berhasil mereduksi lignin, tetapi tidak berpengaruh untuk variasi konsentrasi lainnya (Gambar 1.b; d; e; f).

Puncak bilangan gelombang $1543 \mathrm{~cm}^{-1}$ pada semua pola FTIR diatributkan ke peregangan aromatik cincin $\mathrm{C}=\mathrm{C}$ yang menjadi ciri khas lignin [49], namun pada Gambar 1.c peregangan ini menyebabkan puncak pita menghilang yang berarti terjadi pemisahan lignin, sedangkan pada konsentrasi lainnya (Gambar 1.d; e; f) degradasi lignin tidak sepenuhnya terjadi. Puncak $1230 \quad \mathrm{~cm}^{-1} \quad$ (Gambar 1.a) berhubungan dengan peregangan lentur C$\mathrm{O}$ dari gugus aryl dalam lignin. Terlihat dari Gambar 1.a, perubahan terjadi setelah sampel ditreatmen $\mathrm{NaOH}$ dan $\mathrm{HCl}$, puncak $1230-1364 \mathrm{~cm}^{-1}$ sampel b,c,d,e,f menurun. Hal ini mengindikasikan terjadinya pemisahan hemiselulosa dan lignin setelah proses treatmen ini [50]. Pita bilangan gelombang sekitar $1420-1430 \mathrm{~cm}^{-1}$ dikaitkan dengan bagian kristal dalam selulosa yang diatributkan pada gugus lentur $\mathrm{CH}_{2}$, sedangkan pita pada $894 \mathrm{~cm}^{-1}$ ditujukan ke bagian amorp [46] [51]. Terlihat pada Gambar 1.c, intensitas puncak lebih tajam dari yang lainnya, menunjukkan struktur kristal yang terbentuk lebih baik dari Gambar 1.b, d, e, f. Pemberian $\mathrm{NaOH}$ telah berhasil merusak struktur kristalin lignin dan struktur amorf hemiselulosa sehingga kedua senyawa ini terputus dari ikatan rantai panjang karbon. Selama proses alkali, kation $\mathrm{Na}^{+}$masuk ke dalam pori terkecil selulosa sehingga terjadi reaksi pemutusan ikatan antar senyawa dalam serat. Ikatan $\beta-1,4$ glikosida beserta hemiselulosa akan terdegradasi oleh pemutusan ikatan rantai karbon ini. Perbedaan utama gugus fungsi antara selulosa dengan lignin dan hemiselulosa terletak pada gugus $\mathrm{C}-\mathrm{O}$ glikosida yang teramati untuk semua variasi $\mathrm{NaOH}$, telah mempertajam intensitas serapan infra merah pada puncak $1111-1125 \mathrm{~cm}^{-1}$. Selain itu pergeseran puncak gugus $\mathrm{O}-\mathrm{H}$ pada $3280 \mathrm{~cm}^{-1}$ ke $3360 \mathrm{~cm}^{-1}$ menunjukkan struktur kimia serat berubah ke struktur selulosa murni [45] ditandai dengan terhapusnya lignin dan hemiselulosa.

\section{Karakterisasi XRD}

Gambar 2 menunjukkan difraktogram sampel Cladophora.sp yang diperoleh dari difraktometer X-ray. Pola spektrum dihasilkan oleh diffraction analyzer XRD

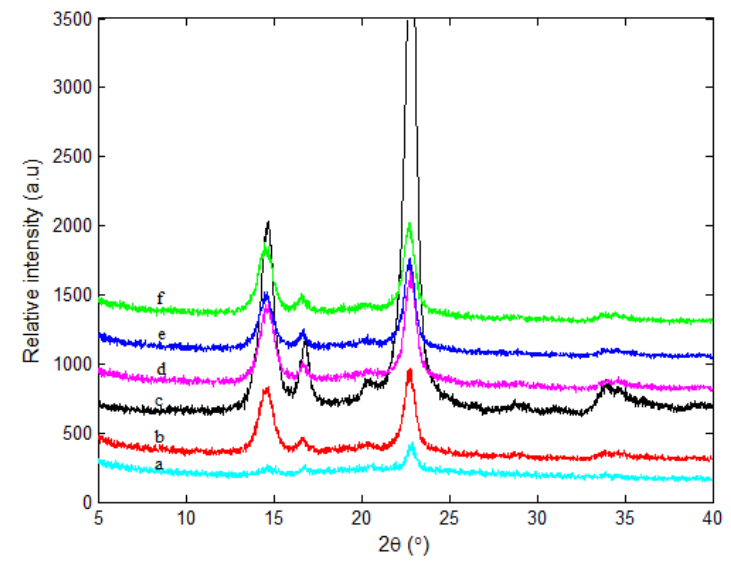

Gambar 2. Difraktogram XRD selulosa

Cladophora dengan konsentrasi $\mathrm{HCl} 5 \%$ dan $\mathrm{NaOH}$ : (a) raw material; (b) 0,4 M; (c) 0,5 M; (d) 0,6 M; (e) 0,7 M dan (f) $0,8 \mathrm{M}$

menggunakan step size 0.017 , dari sumber radiasi X-ray $(\mathrm{Cu}-\mathrm{K} \alpha)$ dengan panjang gelombang $1.540598 \AA$ A. Analisis terhadap data difraktogram ini dapat memberikan 
informasi kristalinitas sampel berdasarkan Persamaan (1).

Tidak seperti hemiselulosa dan lignin, selulosa memiliki struktur kristalin di alam yang dibentuk oleh ikatan hidrogen dan gaya-gaya Van der Waals antar molekul. Difraktogram hasil karakterisasi XRD (Gambar 2.b, c, d, e, f) memberikan informasi struktur kristal selulosa dari Cladophora sp. dengan sebagian besar adalah selulosa I (selulosa kristal) [25], sedangkan untuk Cladophora alami (Gambar 2.a) struktur kristal tidak diperlihatkan oleh puncak-puncak khas kristalin. Selulosa I terdiri atas I $\alpha$ (triclinic structure) dan $\mathrm{I} \beta$ (monoclinic structure) dimana struktur $\mathrm{I} \alpha$ biasanya didominasi polymorph dari sumber alga. Pola XRD untuk berbagai tahap ekstraksi selulosa dari Cladophora sp. dalam Gambar 2.b,c,d,e,f menunjukkan puncak-puncak karakteristik selulosa I, ditandai dari semua pola mengarah pada karakteristik puncak difraksi $2 \theta=14,6^{\circ}(1-10), 16,7^{\circ}(110), 22,8^{\circ}$ (200), 34, $2^{\circ}$ (004), yang mengkonfirmasi bahwa kisi kristal tipe I dari selulosa alam (native cellulose) tetap bertahan setelah ditreatmen hidrolisis alkali-asam [52][53].

Pada Gambar 2, semua sampel menunjukkan puncak pada $2 \theta=22,8^{\circ}$ terkait ke struktur kristalin dari selulosa I, sementara background amorp dikarakterisasi oleh intensitas $2 \theta$ disekitar nilai $18^{\circ}$ [51]. Berdasarkan pola XRD yang diperoleh, semuanya menunjukkan selulosa I, namun pola dengan variasi $\mathrm{NaOH} 0,5 \mathrm{M}$ menunjukkan sebagian besar terdiri dari selulosa I dengan kristalinitas tertinggi, diindikasi oleh puncak-puncak intensitas $2 \theta$ yang lebih tinggi dari lainnya [8][54]. Hal ini menguatkan analisis pola FTIR untuk sampel c dengan variasi $\mathrm{NaOH} 0,5 \mathrm{M}$.

Dari persamaan (1), nilai persen indeks kristalinitas Cladophora alami dan Cladophora yang ditreatmen hidrolisis alkali-asam diperoleh sebesar 58,8, dan 94,0\% (sampel a dan c dalam Gambar 2). Peningkatan index kristalinitas ini menunjukkan keberhasilan tahapan penghapusan hemiselulosa dan lignin pada variasi $\mathrm{NaOH} \quad 0,5$ M. NaOH berfungsi untuk melarutkan lignin dan merusak struktur selulosa dengan melonggarkan serat-serat selulosa sehingga mudah untuk dihidrolisis asam. Meningkatkan konsentrasi $\mathrm{NaOH}$ mampu meningkatkan kandungan selulosa $\mathrm{I} \alpha$ karena makin banyak hemiselulosa dan lignin yang dipecah [38], sebaliknya penambahan konsentrasi $\mathrm{NaOH}$ lebih dari 0,5 $\mathrm{M}$ dengan konsentrasi $\mathrm{HCl}$ tetap, tidak mempengaruhi indeks kristalinitas sebagaimana terlihat pada Gambar 2.d,e,f. Nilai indeks kristalinitas untuk material sampel c $(94,0 \%)$ yang dihitung secara empiris, sesuai dengan fraksinasi selulosa umumnya dengan indeks kristalinitas minimal 91,5\%. Ciri khas dalam pola XRD dari selulosa yang sangat kristalin dinyatakan oleh puncak-puncak sempit berpusat pada nilai $2 \theta$ dari $14,6^{\circ}, 16,8^{\circ}$ dan $22,8^{\circ}$, yang menunjukkan orientasi uniplanar spesifik dari Cladophora selulosa [52][24][55]. Berdasarkan pola $2 \theta$ ini, sampel c $(\mathrm{NaOH}$ $0,5 \mathrm{M})$ sangat kristalin dibanding sampel lainnya.

Ukuran kristal dihitung secara empiris menggunakan persamaan (2), didasarkan pada nilai panjang gelombang, $F W H M$ dan $\theta$ yang diperoleh dari hasil uji XRD pada sampel selulosa. Hasil perhitungan menggunakan data difraktogram XRD sampel a dan c (Gambar 2), diperoleh ukuran kristal 24,22 dan 31,54 nm. Nilai ini memperlihatkan keberhasilan treatmen hidrolisis alkali dalam menghilangkan bagian amorp selulosa, sementara tahap hidrolisis asam berperan dalam indeks kristalinitas dan ukuran kristal selulosa. Proses hidrolisis asam menggerakkan ion hidronium untuk menembus daerah amorf dan mempercepat pembelahan hidrolitik ikatan glikosida, dan melepaskan kristalkristal individual. Selain itu, pertumbuhan ukuran kristal sampel disetiap tahap treatmen dikaitkan dengan perakitan sendiri 
monokristal untuk membentuk selulosa kristal berukuran nano [51].

Penyusunan ulang selulosa Cladophora setelah treatmen hidrolisis menghasilkan pengemasan yang sangat teratur dan makin meningkatkan interaksi hidrogen antar rantai selulosa Cladophora yang menciptakan struktur kristal dengan intensitas puncak yang tinggi. Sintesis dengan metode hidrolis alkali dan hidrolisis asam, telah memperlihatkan pola XRD dengan puncak difraksi yang khas untuk selulosa. Konsentrasi $\mathrm{HCl}$ yang tetap $(5 \%)$ dan konsentrasi $\mathrm{NaOH}$ yang divariasi $(0-$ 0,8 M) pada sintesis selulosa Cladophora, menunjukkan perubahan pola XRD pada puncak-puncak khas selulosa yang mengindikasikan indeks kristalinitas dan ukuran kristal, terlihat dari makin tajam nilai puncak intensitasnya (Gambar 2). Pola XRD juga menunjukkan pemberian jumlah konsentrasi $\mathrm{NaOH}$ sebesar 0,5 $\mathrm{M}$, memberikan nilai terbaik untuk indeks dan ukuran kristal dibandingkan keempat konsentrasi lainnya. Hal ini didukung oleh pergeseran puncak bilangan gelombang pada sampel c di pola FTIR (Gambar 1.c).

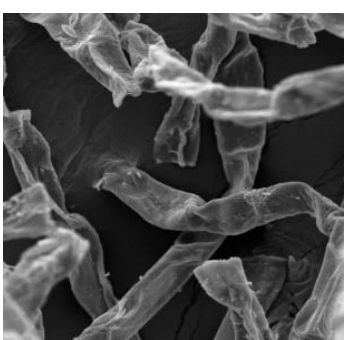

(a)

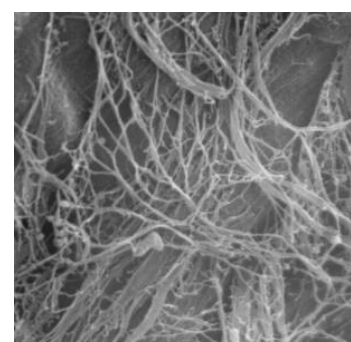

(b)
Gambar 3. Morfologi SEM selulosa Cladophora (a) Cladophora alami, (b) Selulosa Cladophora 0,5 $\mathrm{M}$

\section{Karakterisasi SEM}

Secara umum, morfologi struktur permukaan sampel Cladophora (Gambar 3) menunjukkan perbedaan pada ukuran dan bentuk fisik. Distribusi diameter Cladophora alami adalah 21,34 $\mu \mathrm{m}$ (Gambar 3a), sedangkan selulosa Cladophora berskala nano memiliki distribusi diameter rata-rata $30,63 \mathrm{~nm}$ dan panjang rata-rata $333,78 \mathrm{~nm}$. Perbedaan ini terjadi karena penghilangan sebagian komponen Cladophora alami setelah perlakuan hidrolisis bleaching-alkali-asam untuk membentuk karakteristik serat. Seratserat ini mulai membentuk benang-benang yang terjalin satu sama lain seperti struktur sarang/jaringan (Gambar 3b). Treatmen hidrolisis $\mathrm{HCl}$ memperjelas struktur nanofibril, seperti yang diperlihatkan citra SEM dengan perbesaran lebih tinggi (15.000). Morfologi yang terbentuk bersesuaian dengan penelitian tentang struktur selulosa Cladophora [8][24].

Ukuran dominan selulosa Cladophora secara umum kurang dari $500 \mathrm{~nm}$ dalam panjang, dan sekitar 10 hingga $30 \mathrm{~nm}$ dalam lebar/diameter sehingga dapat dikategorikan sebagai selulosa nanokristal. Komparasi hasil dari pola XRD dan citra SEM membuktikan keberhasilan proses hidrolisis asam $(\mathrm{HCl})$ pada selulosa mikro. Proton asam telah menginvasi dan menghilangkan daerah amorf dalam struktur selulosa dan mempertahankan struktur kristalnya. Hal ini menyebabkan indeks kristalin selulosa Cladophora menjadi lebih tinggi, dan panjang selulosa Cladophora menjadi lebih pendek.

\section{KESIMPULAN}

Cladophora.sp telah disintesis menggunakan hidrolisis bleaching-alkaliasam dan menghasilkan struktur nanoselulosa dari jenis alga hijau air tawar. Perubahan komposisi kimia di setiap langkah hidrolisis alkali pada Cladophora alami diamati menggunakan FTIR, dan menunjukkan adanya peregangan gugus $\mathrm{O}-$ $\mathrm{H}$ pada puncak 3331, 3347, $3360 \mathrm{~cm}^{-1}$, peregangan gugus C-H di sekitar $2929 \mathrm{~cm}^{-1}$, peregangan $\mathrm{C}=\mathrm{O}$ pada $1640-1650 \mathrm{~cm}^{-1}$, dan peregangan lentur $\mathrm{CH}_{2}$ pada $1420-1430 \mathrm{~cm}^{-}$ 1. Komposisi kimia pada sampel c $(\mathrm{NaOH}$ 0,5 M) menunjukkan terbaik dalam menghapus kandungan selulosa amorf 
(lignin dan hemiselulosa) dan memperoleh selulosa kristal. Analisa pola XRD memperkuat perolehan selulosa Cladophora dari sampel c yang sangat kristalin dengan indeks kristalinitas 94,0\%, dan ukuran partikel $31,54 \mathrm{~nm}$, sedangkan analisa pada citra SEM menunjukkan pembentukan jaringan nanofibril seperti sarang (web) dengan diameter rata-rata $30,63 \mathrm{~nm}$, sehingga dapat dikatakan bahwa sintesis selulosa dengan nilai konsentrasi $\mathrm{NaOH} \quad 0,5 \mathrm{M}$ telah memberikan hasil terbaik.

\section{UCAPAN TERIMAKASIH}

Penelitian ini terselenggara atas dukungan dari Hibah Penelitian Program Doktor dengan nomor kontrak 3975/ UN26.21/PN/2021 Tanggal 14 Juli 2021, diselenggarakan oleh Kementerian Pendidikan, Kebudayaan, Riset dan Teknologi Republik Indonesia yang bekerjasama dengan Lembaga Penelitian dan Pengabdian Masyarakat, Universitas Lampung.

\section{DAFTAR PUSTAKA}

[1] I. Linkov, M. E. Bates, L. J. Canis, T. P. Seager, and J. M. Keisler, "A decision-directed approach for prioritizing research into the impact of nanomaterials on the environment and human health," Nat. Nanotechnol., vol. 6, no. 12, pp. 784787, 2011, doi: 10.1038/nnano.2011.163.

[2] H. Zhu, W. Luo, P.N. Ciesielski, Z. Fang, J.Y. Zhu, G. Henrikson, M.E. Himmel, L. Hu, "Wood-Derived Materials for Green Electronics, Biological Devices, and Energy Applications," Chem. Rev., vol. 116, no. 16, pp. 9305-9374, 2016, doi: 10.1021/acs.chemrev.6b00225.

[3] G. Lu, S. Li, Z. Guo, O.K. Farha,
B.G. Hauser, X. Qi, Y. Wang, X. Wang, S. Han, X. Liu, J. S. Duchene, H. Zhang, Q. Zhang, X. Chen, J. Ma, S. C. J. Loo, W.D. Wei, Y. Yang, J.T. Hupp, F. Huo, "Imparting functionality to a metal-organic framework material by controlled nanoparticle encapsulation," Nat. Chem., vol. 4, no. 4, pp. 310-316, 2012, doi: 10.1038/nchem.1272.

[4] F. I. Ditzel, E. Prestes, B. M. Carvalho, I. M. Demiate, and L. A. Pinheiro, "Nanocrystalline cellulose extracted from pine wood and corncob," Carbohydr. Polym., vol. 157, pp. 1577-1585, 2017, doi: 10.1016/j.carbpol.2016.11.036.

[5] K. H. Lin, T. Enomae, and F. C. Chang, "Cellulose Nanocrystal Isolation from Hardwood Pulp using Various Hydrolysis Conditions," Molecules, vol. 24, no. 20, pp. 3-5, 2019 , doi: 10.3390/molecules24203724.

[6] C. Félix, R.Félix, A.M. Carmona, A.P. Januário, P.D.M. Dias, T.F.L. Vicente, J. Silva, C. Alves, R. Pedrosa, S.C. Novais and M.F.L. Lemos, "Cosmeceutical potential of grateloupia turuturu: Using low-cost extraction methodologies to obtain added-value extracts," Appl. Sci., vol. 11, no. 4, pp. 1-16, 2021, doi: 10.3390/app11041650.

[7] A. F. Tarchoun, D. Trache, and T. M. Klapötke, "Microcrystalline cellulose from Posidonia oceanica brown algae: Extraction and characterization," Int. J. Biol. Macromol., vol. 138, pp. 837845, 2019, doi: 10.1016/j.ijbiomac.2019.07.176.

[8] Z. Xiang, W. Gao, L. Chen, W. Lan, and J. Y. Z. Troy, "A comparison of cellulose nanofibrils produced from 
Cladophora glomerata algae and bleached eucalyptus pulp," Cellulose, vol. 23, no. 1, pp. 493-503, 2016, doi: 10.1007/s 10570-015-0840-7.

[9] N. Lin and A. Dufresne, "Nanocellulose in biomedicine: Current status and future prospect," Eur. Polym. J., vol. 59, pp. 302-325, 2014 , 10.1016/j.eurpolymj.2014.07.025.

[10] H. G. de Oliveira Barud, R.R. da Silva, H. da Silva Barud, A. Tercjak, J. Gutierrez, W.R., Lustri, O.B. de Oliveira and S.J.L. Ribeiro, "A multipurpose natural and renewable polymer in medical applications: Bacterial cellulose," Carbohydr. Polym., vol. 153, pp. 406-420, 2016, doi: 10.1016/j.carbpol.2016.07.059.

[11] I. F. Almeida, T. Pereira, N.H.C.S. Silva, F.P. Gomes, A.J.D. Silvestre, C.S.R. Freire, J.M. Sousa Lobo and P.C. Costa, "Bacterial cellulose membranes as drug delivery systems: An in vivo skin compatibility study," Eur. J. Pharm. Biopharm., vol. 86, no. 3, pp. 332-336, 2014, doi: 10.1016/j.ejpb.2013.08.008.

[12] X. Feng, X. Meng, J. Zhao, M. Miao, L.Shi, S. Zhang, and J. Fang, "Extraction and preparation of cellulose nanocrystals from dealginate kelp residue: structures and morphological characterization," Cellulose, no. April, 2015, doi: 10.1007/s10570-015-0617-z.

[13] D. Swantomo, Giyatmi, S. H. Adiguno, and D. Wongsawaeng, "Preparation of microcrystalline cellulose from waste cotton fabrics using gamma irradiation," Eng. J., vol. 21 , no. 2 , pp. 173-182, 2017, doi: 10.4186/ej.2017.21.2.173.
[14] R. A. Ilyas, S. M. Sapuan, and M. R. Ishak, "Isolation and characterization of nanocrystalline cellulose from sugar palm fibres (Arenga Pinnata)," Carbohydr. Polym., vol. 181, pp. 1038-1051, 2018, doi: 10.1016/j.carbpol.2017.11.045.

[15] H. Ren, J. Shen, J. Pei, Z. Wang, Z. Peng, S. Fu, and Y. Zheng, "Characteristic microcrystalline cellulose extracted by combined acid and enzyme hydrolysis of sweet sorghum," Cellulose, vol. 26, no. 15, pp. 8367-8381, 2019, doi: 10.1007/s10570-019-02712-6.

[16] H. P. S. A. Khalil, Y. Davoudpour, N. Islam, M.Asniza, K. Sudesh, R. Dungani and M. Jawaid, "Production and modification of nanofibrillated cellulose using various mechanical processes: A review," Carbohydr. Polym., vol. 99, pp. 649-665, 2014, doi: 10.1016/j.carbpol.2013.08.069.

[17] A. Dufresne, "Nanocellulose: a new ageless bionanomaterial," Mater. Today, vol. 16, no. 6, pp. 220-227, 2013, doi: 10.1016/j.mattod.2013.06.004.

[18] T. Abitbol, A. Rivkin, Y. Cao, Y. Nevo, E. Abraham, T. Ben-shalom, S. Lapidot, and O. Shoseyov, “ Nanocellulose, a tiny fiber with huge applications," Curr. Opin. Biotechnol., vol. 39, no. I, pp. 76-88, 2016 , doi: 10.1016/j.copbio.2016.01.002.

[19] D. Trache, M.H. Hussin, C.T. Hui Chuin, S. Sabar, M.R.N. Fazita, O.F.A. Taiwo, T.M. Hasan and M.K.M. Haafiz, "Microcrystalline cellulose: Isolation, characterization and bio-composites application-A 
review," Int. J. Biol. Macromol., vol. 93, no. June 2018, pp. 789-804, 2016, doi: 10.1016/j.ijbiomac.2016.09.056.

[20] H. Kargarzadeh, M. Ioelovich, and I. Ahmad, Methods for Extraction of Nanocellulose from Various, 1st ed. Wiley-VCHVerlag GmbH\& Co. KGaA, 2017.

[21] I. Siró and D. Plackett, "Microfibrillated cellulose and new nanocomposite materials: A review," Cellulose, vol. 17, no. 3, pp. 459-494, 2010, doi: 10.1007/s10570-010-9405$\mathrm{y}$.

[22] L. Bacakova, J. Pajorova, M. Tomkova, R. Matejka, A. Broz, J. Stepanovska, S. Prazak, A. Skogberg, S. Siljande and P. Kallio, "Applications of nanocellulose/nanocarbon composites: Focus on biotechnology and medicine," Nanomaterials, vol. 10, no. 2, pp. 1-32, 2020, doi: 10.3390/nano10020196.

[23] A. Mihranyan, A. Piñas, R. Karmhag, M. Strømme, and R. Ek, "Moisture sorption by cellulose powders of varying crystallinity," Int. J. Pharm., vol. 269, pp. 433-442, 2004, doi: 10.1016/j.ijpharm.2003.09.030.

[24] A. Mihranyan, "Cellulose from Cladophorales Green Algae: From Environmental Problem to High-Tech Composite Materials," J. Appl. Polym. Sci., vol. 119, pp. 2449-2460, 2011, doi: 10.1002/app.

[25] D. H. Camacho, S. R. A. E. C. Gerongay, and J. P. C. Macalinao, "Cladophora Cellulose - Polyaniline Composite For Remediation Of Toxic Chromium ( VI )," Cellul. Chem. Technol., vol. 47, no. 1-2, pp. 125132, 2013.
[26] S. W. Suciyati, P. Manurung, S. Sembiring, and R. Situmeang, "Comparative study of Cladophora sp. cellulose by using FTIR and XRD," J. Phys. Conf. Ser., vol. 1751, no. 1, 2021, doi: 10.1088/17426596/1751/1/012075.

[27] S. Zhou, L. Nyholm, M. Strømme, and Z. Wang, "Cladophora Cellulose : Unique Biopolymer Nanofibrils for Emerging Energy , Cladophora Cellulose: Unique Biopolymer Nano fi brils for Emerging Energy , Environmental, and Life Science Applications," Acc. Chem. Res. 2019, 52, 8, 2232-2243, vol. 52, no. July, pp. 2232-2243, 2019, doi: 10.1021/acs.accounts.9b00215.

[28] O. Gustafsson, L. Manukyan, and A. Mihranyan, "High-Performance Virus Removal Filter Paper for Drinking Water Purification," Glob. Challenges, vol. 2, no. 7, p. 1800031, 2018, doi: $10.1002 / g c h 2.201800031$.

[29] A. Mihranyan, L. Nyholm, A. E. Garcia Bennett, and M. Strømme, "A novel high specific surface area conducting paper material composed of polypyrrole and Cladophora cellulose," J. Phys. Chem. B, vol. 112, no. 39, pp. 12249-12255, 2008, doi: $10.1021 / \mathrm{jp} 805123 \mathrm{w}$.

[30] G. Nystrom, A. Razaq, M. Strømme, L. Nyholm, and A. Mihranyan, "Ultrafast All-Polymer Paper-Based Batteries," nano Lett., vol. 9, no. 10, pp. 3635-3639, 2009.

[31] P. Phanthong, P. Reubroycharoen, X. Hao, and G. Xu, "Nanocellulose: Extraction and application," Carbon Resour. Convers., vol. 1, no. 1, pp. 32-43, 2018, doi: 
10.1016/j.crcon.2018.05.004.

[32] E. Abraham, B. Deepa, L.A. Pothan, M. Jacob, S. Thomas, U. Cvelbar and R. Anandjiwa, "Extraction of nanocellulose fibrils from lignocellulosic fibres: A novel approach," Carbohydr. Polym., vol. 86, no. 4, pp. 1468-1475, 2011, doi: 10.1016/j.carbpol.2011.06.034.

[33] G. Moreno, K. Ramirez, M. Esquivel, and G. Jimenez, "Isolation and Characterization of Nanocellulose Obtained from Industrial Crop Waste Resources by Using Mild Acid Hydrolysis," J. Renew. MAaer., vol. 6, no. 4, pp. 362-369, 2018, doi: 10.7569/JRM.2017.634.

[34] M. Z. Karim, Z. Z. Chowdhury, S. B. A. Hamid, and M. E. Ali, "Statistical optimization for acid hydrolysis of microcrystalline cellulose and its physiochemical characterization by using metal ion catalyst," Materials (Basel)., vol. 7, no. 10, pp. 69826999, 2014, doi: 10.3390/ma7106982.

[35] T. Moberg, K. Sahlin, K. Yao, S. Geng, G. Westman, Q. Zhou, K. Oksman, and M. Rigdahl, "Rheological properties of nanocellulose suspensions: effects of fibril/particle dimensions and surface characteristics," Cellulose, vol. 24, no. 6, pp. 2499-2510, 2017, doi: 10.1007/s 10570-017-1283-0.

[36] F. Kallel, F. Bettaieb, R. Khiari, A. García, J. Bras, and S. E. Chaabouni, "Isolation and structural characterization of cellulose nanocrystals extracted from garlic straw residues," Ind. Crops Prod., vol. 87, pp. 287-296, 2016, doi: 10.1016/j.indcrop.2016.04.060.
[37] H. Yu, Z. Qin, B. Liang, N. Liu, Z. Zhou, and L. Chen, "Facile extraction of thermally stable cellulose nanocrystals with a high yield of $93 \%$ through hydrochloric acid hydrolysis under hydrothermal conditions," $J$. Mater. Chem. A, vol. 1, no. 12, pp. 3938-3944, 2013, doi: $10.1039 / \mathrm{c} 3 \mathrm{ta} 01150 \mathrm{j}$.

[38] I. G. N. J. A. Prasetia, S. Deviana, T. Damayanti, A. Cahyadi, and I. M. A. G. Wirasuta, "The Effect of $\mathrm{NaOh}$ Concentration in Delignification Process on Microcrystalline Cellulose from Green Algae (Cladophora sp.) as the Renewable Marine Product," $J$. Pharm. Sci. Community, vol. 15, no. 2, pp. 68-71, 2018, doi: 10.24071/jpsc. 1521026 .

[39] D. Klemm et al., "Nanocelluloses: A new family of nature-based materials," Angew. Chemie - Int. Ed., vol. 50, no. 24 , pp. 5438-5466, 2011, doi: 10.1002/anie.201001273.

[40] D. Klemm, F. Kramer, S. Moritz, T. Lindström, M. Ankerfors, D. Gray and A. Dorris, "Nanocellulose as a natural source for groundbreaking applications in materials science: Today's state," Mater. Today, vol. 21, no. 7, pp. 720-748, 2018, doi: 10.1016/j.mattod.2018.02.001.

[41] D. Trache, K. Khimeche, A. Mezroua, and M. Benziane, "Physicochemical properties of microcrystalline nitrocellulose from Alfa grass fibres and its thermal stability," J. Therm. Anal. Calorim., vol. 124 , no. 3 , pp. 1485-1496, 2016, doi: 10.1007/s10973-016-5293-1.

[42] M. E. Fuller, C. Andaya, and K. Mcclay, "Evaluation of ATR-FTIR for analysis of bacterial cellulose 
impurities," J. Microbiol. Methods, vol. 144, no. October 2017, pp. 145151, 2018, doi: 10.1016/j.mimet.2017.10.017.

[43] M. Cellulose and H. Wang, "FTIR , XRD and SEM Analysis of Microcrystalline Cellulose ( MCC ) Fibers from Corncorbs in Alkaline Treatment FTIR , XRD and SEM Analysis of Microcrystalline Cellulose ( MCC ) Fibers from Corncorbs in Alkaline Treatment," $J$. Phys. Conf. Ser. 1028 012199, no. Mcc, pp. 1-8, 2018.

[44] H. Kamal and S. Lotfy, "Characterization and some properties of cellulose acetate-copolyethylene oxide blends prepared by the use of gamma irradiation ScienceDirect Journal of Radiation Research and Applied Characterization and some properties of cellulose acetate-co-polyethyle," $J$. Radiat. Res. Appl. Sci., no. March, 2014, doi: 10.1016/j.jrras.2014.01.003.

[45] L. H. Saputri and R. Sukmawan, "Pengaruh Proses Blending dan Ultrasonikasi terhadap Struktur Morfologi Ekstrak Serat Limbah Batang Kelapa Sawit untuk Bahan Baku Bioplastik ( Selulosa Asetat )," Rekayasa, vol. 13, no. 1, pp. 15-21, 2020, doi: https://doi. org/10.21107/rekayasa.v13i1.6180.

[46] V. Hospodarova, E. Singovszka, and N. Stevulova, "Characterization of Cellulosic Fibers by FTIR Spectroscopy for Their Further Implementation to Building Materials," Am. J. Anal. Chem., vol. 9, pp. 303-310, 2018, doi: 10.4236/ajac.2018.96023.
[47] S. Kumar, Y. S. Negi, and J. S. Upadhyaya, "Studies on characterization of corn cob based nanoparticles," no. September 2015, 2010, doi: 10.5185/amlett.2010.9164.

[48] M. Camacho, Y.R.C. Ureña, M. Lopretti, L.B. Carballo, G. Moreno, B. Alfaro, and J.R. Vega Baudrit, "Synthesis and characterization of nanocrystalline cellulose derived from Pineapple peel residues," $J$. Renew. Mater., vol. 5, no. 3-4, pp. 271-279, 2017, doi: 10.7569/JRM.2017.634117.

[49] F. Xu, J. Yu, T. Tesso, F. Dowell, and D. Wang, "Qualitative and quantitative analysis of lignocellulosic biomass using infrared techniques: A mini-review," Appl. Energy, vol. 104, pp. 801-809, 2013, doi: 10.1016/j.apenergy.2012.12.019.

[50] H. Kargarzadeh, I. Ahmad, I. Abdullah, A. Dufresne, S. Y. Zainudin, and R. M. Sheltami, "Effects of hydrolysis conditions on the morphology, crystallinity, and thermal stability of cellulose nanocrystals extracted from kenaf bast fibers," Cellulose, vol. 19, no. 3, pp. 855-866, 2012, doi: 10.1007/s10570-012-9684-6.

[51] M. R. Sucaldito and D. H. Camacho, "Characteristics of unique $\mathrm{HBr}$ hydrolyzed cellulose nanocrystals from freshwater green algae (Cladophora rupestris) and its reinforcement in starch-based film," Carbohydr. Polym., vol. 169, no. February 2018, pp. 315-323, 2017, doi: 10.1016/j.carbpol.2017.04.031.

[52] A. D. French, "Idealized powder diffraction patterns for cellulose polymorphs," Cellulose, vol. 21, no. 
2, pp. 885-896, 2014, doi: 10.1007/s 10570-013-0030-4.

[53] A. W. Pratama, B. Piluharto, D. Indarti, T. Haryati, and H. S. Addy, "Pengaruh Konsentrasi Asam Terhadap Sifat Fisik dan Muatan Permukaan Selulosa Termodifikasi," ALCHEMY J. Penelit. Kim., vol. 15, no. 2, p. 315, 2019, doi: 10.20961/alchemy.15.2.33756.315328.

[54] A. Mihranyan, K. Edsman, and M. Strømme, "Rheological properties of cellulose hydrogels prepared from Cladophora cellulose powder," Food Hydrocoll., vol. 21, no. 2, pp. 267272, 2007 , doi: 10.1016/j.foodhyd.2006.04.003.

[55] M. Wada, T. Kondo, and T. Okano, "Thermally induced crystal transformation from cellulose I $\alpha$ to I $\beta$," Polym. J., vol. 35, no. 2, pp. 155159 , 2003 , doi: 10.1295/polymj.35.155.

[1] D. E. Knuth, Fundamental Algorithms, $2^{\text {nd }}$ ed. Reading, MA: Addison-Wesley, 1973.

[2] V. Bush, "As We May Think", The Atlantic, vol. 176, no.1, pp. 101-108, July 1945.

[3] X. Liu, "A Local Comparison Algorithm for VLSI Circuit Verification", M.Comp.Sc. thesis, TUNS, Halifax, NS, 1993. 
Sri Wahyu Suciyati: Efek Variasi Konsentrasi $\mathrm{NaOH}$ pada Pembentukan Struktur Selulosa Cladaphora sp 